\title{
A elite do Partido Republicano se apropria da "Revolução"
}

\author{
The Republican Party's elite appropriates the "Revolution"
}

\author{
Luiz Alberto Grijó ${ }^{1}$
}

lgrijo@uol.com.br

\footnotetext{
' Professor do Departamento de História e do PPG em História da UFRCS, Mestre em Ciência Política pela UFRGS, Doutor em História Social pela UFF.
}

\begin{abstract}
Resumo. Este trabalho analisa a apropriação operada pela elite do Partido Republicano Rio-Grandense (PRR) das ideias e ideais que supostamente nortearam a ação dos líderes do movimento farroupilha. Busca avaliar a importância da identificação entre a revolta iniciada em 1835 e o movimento republicano da década de 1880 para os líderes do PRR, principalmente como forma de impugnar a legitimidade dos seus adversários políticos de então, os seguidores de Gaspar Silveira Martins, em se apresentarem como "herdeiros dos farrapos".
\end{abstract}

Palavras-chave: história do Rio Grande do Sul, ideias políticas no Rio Grande do Sul, partidos políticos no Rio Grande do Sul.

Abstract. The article discusses the appropriation of the ideas and ideals that allegedly guided the action of the leaders of the "Farroupilha" Movement by the elite of the Republican Part of Rio Grande do Sul (Partido Republicano Rio-Grandense [PRR]). It assesses the importance of the identification between the revolt began in 1835 and the republican movement of the '1880s for the leaders of PRR, mainly as a way of refuting their political opponents' - namely, the followers of Gaspar Silveira Martins - legitimacy as they presented themselves as "heirs of the "farrapos".

Key words: history of Rio Grande do Sul, political ideas in Rio Grande do Sul, political parties in Rio Grande do Sul.

Em 1835, estourou no Rio Grande do Sul um movimento armado que desafiava e questionava a legitimidade da soberania do governo central brasileiro na região. Não foi à época um caso isolado. A chamada Revolução Farroupilha fez parte do contexto do período regencial, no qual eclodiram diversos outros movimentos de rebelião em várias províncias imperiais.

Este trabalho, porém, não tem por objeto uma abordagem histórica ou sociológica do referido movimento. Ele visa, por outro lado, analisar de que maneira e a partir de quais ideias dois ativistas político-partidários riograndenses, que pregavam o estabelecimento da República no Brasil, procuraram se apropriar da Revolução Farroupilha a fim de instrumentalizar esta 
apropriação na luta político-partidária da década de 80 do século XIX.

Para o caso do Rio Grande do Sul, é importante ressaltar que foi somente em 1882 que se fundou e estruturou um partido republicano local, o Partido Republicano Rio-Grandense (PRR). Para isto em muito concorreu a iniciativa de, entre outros, recém-formados bacharéis em direito pela academia do Largo de São Francisco na cidade de São Paulo, quatro dos quais se tornariam posteriormente algumas das principais lideranças do PRR: José Gomes Pinheiro Machado, Antônio Augusto Borges de Medeiros, Júlio Prates de Castilhos e Joaquim Francisco de Assis Brasil. Todos eles participaram ativamente do chamado período da propaganda republicana, mas vou aqui me concentrar em apenas dois: Júlio de Castilhos e Assis Brasil.

Dentre os diversos tipos de recursos que herdaram ou adquiriram para o enfrentamento político-partidário, creio não ser exagerado afirmar que ambos se destacariam também como ideólogos do movimento republicano rio-grandense e brasileiro. Castilhos, inclusive, foi o responsável pelo que viria a ser chamado de "castilhismo", um conjunto de princípios mais ou menos inspirados em textos de Auguste Comte que se tornariam o referencial simbólico, institucional e formal do governo do Estado do Rio Grande do Sul de 1891 a 1930 (ver Boeira, 1980; Rodríguez, 1980). Já Assis Brasil, antes do rompimento de relações com Castilhos em 1891, também contribuiu com textos, pronunciamentos e outras tantas ações para a estruturação e divulgação dos princípios norteadores do PRR. Teve, porém, mais sucesso ainda após deixar o partido, quando acabou se tornando o maior ideólogo das oposições ao PRR, sendo conhecido por esposar ideias de cunho "liberal" em contraposição às ideias "positivistas" dos governantes.

A este respeito, Boeira salienta que "mesmo Assis Brasil, que após 1891 divergirá cada vez mais do positivismo, não se distingue inicialmente dos demais ideólogos do PRR nas suas manifestações públicas" (Boeira, 1980, p. 38). Como se pode observar adiante, as ideias políticas de Assis Brasil neste período em foco se aproximavam muito das então muito difundidas e um tanto difusas ideias mais geralmente designadas de "cientificistas" no Brasil, que incluíam não só o comtismo, mas várias outras doutrinas filosófico-políticas. Creio, porém, não ser adequado rotulá-lo como um "positivista", como já parecia ser Júlio de Castilhos, embora não fosse ainda por certo o "ideólogo liberal" que se tornaria depois do rompimento com o PRR. Como o próprio Boeira admite, foi apenas "progressivamente" que os "programas e os documentos do PRR passaram [...] a valer-se do vocabulário positivista" (Boeira, 1980, p. 38). Ou seja, nos inícios da organização do partido, a elite do PRR não se distinguia propriamente por ser "positivista", sendo que a sigla partidária abrigava desde os que já se declaravam mais ou menos abertamente como tais, Castilhos e Demétrio Ribeiro, para citar os mais conhecidos, até outros tantos que pregavam outros tipos de ideias.

Antes, porém, que as divergências afastassem Castilhos e Assis Brasil, foram eles não só companheiros de partido. Antes de seguirem para São Paulo a fim de estudar direito, teriam se conhecido em Porto Alegre, quando frequentaram juntos o Colégio Gomes. No início da década de 1880, ambos ainda estudantes na Academia paulistana, foram apontados por um contemporâneo, Lúcio de Mendonça, como "inseparáveis como Cástor e Pólux" (in Franco, 1988, p. 21). Foi então que Assis Brasil escreveu um livro de caráter historiográfico: História da República Rio-Grandense (Assis Brasil, 1882). Neste relativamente longo texto, o redator aborda os primeiros anos do movimento farroupilha. Júlio de Castilhos, por seu turno, em 1884, já formado, vivendo novamente no Rio Grande do Sul e sendo o principal redator do jornal fundado pelo PRR, A Federação, escreve um artigo chamado Movimento Republicano (Castilhos, 1928 [1884]), no qual aborda também o mesmo assunto.

Por que estariam eles preocupados em se ocuparem de um movimento ocorrido em uma época já um tanto afastada no tempo? Somente por estarem engajados no movimento republicano e ter existido em sua província natal, há uns 40 anos, uma organização política que se apresentava como republicana? Principalmente Castilhos, já um forte simpatizante das ideias de Comte, mas mesmo Assis Brasil, quereriam reviver no Rio Grande do Sul a proclamação da República Rio-Grandense de 1836 e sua estrutura institucional posteriormente esboçada?

O que é analisado aqui, tendo como fonte mais o texto de Assis Brasil do que o pequeno artigo de Castilhos, são as condições que podem esclarecer o porquê desta utilização do movimento farroupilha por parte destes simpatizantes e militantes do regime republicano do final do século XIX. Por outro lado, busco também tentar definir a partir de quais ideias se forjou a imagem daquele movimento que poderia servir ao que se propunham os líderes do PRR apresentar como alternativa política para o Brasil e o Rio Grande do Sul na década de 1880.

Assim, vou me concentrar especialmente no campo da história das ideias enquanto "proposição epistemológica que garante a validade de um certo tipo de conhecimento histórico no qual as ideias constituem seu objeto". Falcon salienta ainda que "hoje em dia [...], as indagações se dirigem ao texto ou ao discurso, e também à mensagem, mas sempre de olho na intertextualidade e na contextualização" (Falcon, 1997, p. 92, 95). Estas observações remetem para 
a necessidade de que o historiador que tome as ideias como objeto não as conceba como descoladas dos agentes produtores e dos contextos de sua produção, entendidos ambos como resultados de processos históricos. Assim, as ideias passam a ser entendidas como o resultado de um cruzamento entre processos que seriam os da: (i) dinâmica histórica geral e específica, ou seja, o contexto histórico; (ii) produção e posição relativa do autor e seu discurso entre tantos outros autores e discursos, ou seja, o que, quem e como se posiciona contra o que, quem e como enquanto produtor e divulgador de ideias; (iii) publicização e recepção dos conteúdos, ou seja, como e quem é atingido, os destinatários das ideias.

Posta a questão desta forma, creio que se torna possível tomar as ideias como objeto privilegiado de estudo de modo que se possa escapar da dicotomia idealismo/ materialismo, pois, ao mesmo tempo em que, contra o materialismo, as ideias ganham especificidade e importância, contra o idealismo, não são entendidas como entidades autossuficientes ou sustentáculos da realidade.

Inicialmente, é importante apresentar um pouco de certos contextos pelos quais transitaram Castilhos e Assis Brasil. Ambos eram filhos de estancieiros do interior da província, embora este último viesse da região sul e fosse originário de um grupo familiar economicamente abastado e o primeiro viesse da região central e oriundo de um grupo familiar mais modesto. Mesmo assim, os dois puderam estudar em Porto Alegre e, o que era razoavelmente dispendioso à época, na Academia de Direito de São Paulo. Nesta, compartilharam um universo caracterizado assim por Oliveira Viana ao se referir às academias de ensino superior do Império, os "centros de idealismo político nacional, os mais importantes por serem justamente os focos de sua elaboração":

O papel exercido pelas academias em nossa evolução política não tem sido, porém, apenas esse, que resultou do fato de serem elas aqui os centros principais da elaboração do idealismo europeu: também atuaram naquela época incomparavelmente mais do que hoje - como agentes da disseminação desse idealismo, tal como o periodismo e a publicistica. E isto porque, dado o seu número limitado, para elas confluiam os melhores elementos das nossas novas gerações provincianas, egressos dos recessos das propriedades rurais e afluidos de todos os pontos do país (in Venâncio Filho, 1982, p. 162-163).

Ainda quanto a este aspecto, Adorno refere que, na Academia paulistana, o "critério que mediatizou as relações sociais no [seu] interior [... foi] a militância política. A atividade didático-pedagógica foi essencialmente política menos pelos conteúdos doutrinários transmitidos em sala de aula [... do que] no sentido de estimular um aprendizado [...] de que a militância política deveria se orientar por critérios intelectuais"(Adorno, 1988, p. 154).

Descrevendo o contexto da escola de direito, Adorno chega a estas conclusões mostrando o quão ampla ou aberta ao mundanismo e a outras atividades e preocupações paralelas era o que se chamava "vida acadêmica", tanto sob o ponto de vista dos professores quanto dos alunos. Prova disto é que o controle de frequência era deficiente, as lições repetidas ano a ano eram lidas em sala de aula, os manuais escolares eram precários, os conflitos internos entre os alunos, entre alunos e professores e mesmo no interior do corpo docente eram constantes. Enfim, há uma série de indicadores que apontam que não era a atividade didático-pedagógica que centralizava as preocupações dos membros da escola. Ao contrário. Eram as atividades paralelas às propriamente escolares que criavam o espaço de socialização e aprendizagem mais importante. Estes eram os clubes e sociedades mais ou menos secretos aos quais os alunos se filiavam, eram as pensões e "repúblicas" nas quais moravam, eram os jornais e revistas que organizavam, redigiam e editavam. Adorno complementa:

$\mathrm{Na}$ imprensa, veiculavam-se grandes modelos de pensamento que conferiam forma à prática política de defender e de atacar sobre o que se via às voltas do mundo acadêmico: as condiçôes da agricultura, a vida partidária, a prática eleitoral etc. [...A academia] foi uma verdadeira escola de costumes. Humanizou o embrutecido estudante proveniente do campo; civilizou os hábitos enraizados num passado imediatamente colonial; disciplinou o pensamento no sentido de permitir pensar a coisa politica como atividade dirigida por critérios intelectuais (Adorno, 1988, p. 155).

Tanto Castilhos quanto Assis Brasil participaram de associações deste tipo e contribuíram para fundar e redigir periódicos. Ambos chegaram a organizar um jornal republicano denominado $A$ Evolução. É, pois, importante frisar que a atividade político-partidária era privilegiada neste contexto do mundo acadêmico e que os dois agentes em questão foram ativos militantes republicanos, ao lado de outros estudantes, rio-grandenses ou não, que cursavam a escola de direito em São Paulo na mesma época. Isto é significativo para que se possa entender o tipo de apropriação do passado que eles passam a operar. Trata-se de uma apropriação que se poderia chamar de militante. Ou seja, o passado é tomado como um recurso instrumentalizável para a luta político-partidária no presente, ao contrário do que seria uma apropriação propriamente acadêmica, ou mesmo intelectualmente diletante do mesmo, mais preocupada com 
critérios de rigor e objetividade científicos e/ou tendo como finalidade o conhecimento pelo conhecimento.

No sentido da apropriação militante do passado, o artigo de Castilhos parece dar a chave do entendimento do por que seria necessário dar conta do movimento de 1835. A chamada "Revolução Farroupilha" é vista como "um dos nossos mais notáveis pronunciamentos democráticos”, que fez do Rio Grande do Sul “a província mais republicana do Brasil”. Desse modo, Castilhos traça uma linha de continuidade entre aquele momento do passado e o momento no qual escreve, quando havia poucos anos se estruturara o PRR: "o jovem partido [que] cresce constantemente, e não tardará a ter representação na própria assembleia provincial". O tal "pronunciamento democrático", "infelizmente, porém, pela ambição indisciplinada de alguns homens que souberam explorar os sentimentos tradicionais deste grande povo, pela tibieza condenável de outros, pela culpada indiferença de quase todos, a uma longa apatia esteve votado o viril espírito republicano que animou o passado do Rio Grande" (Castilhos, 1928 [1884], p. 3, grifos meus).

Note-se que "democrático", no sentido em que Castilhos emprega o termo, não se trata de uma forma de governo, mas de uma espécie de enaltecimento da "força popular", das "virtudes do povo", de acordo com sua "natureza". É quase o sentido de uma tradução literal do termo grego como "poder do povo".

Por outro lado, referindo-se ao Partido Liberal e ao seu líder no Rio Grande do Sul, Gaspar Martins, escreveu: "depois de haver entre nós usurpado ilegitimamente tradições que não lhe pertencem, depois de haver abusado sem moderação do poder moral que elas the deram, esse partido cavou, finalmente, o seu irremediável descrédito, e vive atualmente da força que lhe dá a incontestável capacidade do seu diretor supremo"(Castilhos, 1928 [1884], p. 5, grifos meus).

Neste âmbito da atividade político-partidária dirigida por critérios intelectuais, na expressão de Adorno, era fundamental para a ação proselitista dos membros do PRR tentarem se apropriar das "tradições", até então "usurpadas" pelos adversários, segundo as palavras de Castilhos. Desde a estruturação do Partido Liberal dito "histórico" no Rio Grande do Sul, no início da década de 1860, e com a emergência e consolidação da liderança de Gaspar Silveira Martins no partido, um dos seus referenciais discursivos básicos fora a identificação com a "Revolução Farroupilha". Por seu caráter e discurso "reformista" em termos políticos, o partido "passou a receber adesões em número sempre crescente, incluindo ex-farroupilhas (como, por exemplo, Canabarro)". Por um lado, "barrou as pretensões dos conservadores no Rio Grande do Sul”, mas, por outro, "também impediu que, na década de setenta, se estruturas- se na província um partido republicano em consonância com o Manifesto do Rio de Janeiro em fins de 1870. Os republicanos que desejaram atuar politicamente, o fizeram abrigados no Partido Liberal", o que teria motivado que um partido republicano no Rio Grande do Sul só viesse a se estruturar a partir do início da década de 1880, embora já existisse um Clube Republicano em Porto Alegre desde 1878 (Piccolo, 1998, p. 55, 62).

Esta disputa pela apropriação de um "passado farroupilha" remete a um plano propriamente cultural de disputa por princípios de divisão do mundo social, uma disputa pela representação legítima do passado (ver Bourdieu, 1989, p. 174, 185-186). Castilhos, ao impugnar a legitimidade da visão anteriormente apropriada e difundida pelos seus adversários, propõe uma outra visão da "tradição" que, desta vez, a aproximava das ideias que buscava divulgar e difundir. O que os adversários pregavam era "usurpação" e servia apenas para "explorar os sentimentos do grande povo", ou seja, seria mero engodo. Os que de fato "representariam" uma suposta "verdade" sobre o movimento farroupilha e sua suposta "essência republicana" seriam os membros do PRR.

Depois de vitoriosos nos conflitos da primeira década do regime republicano, os dirigentes do PRR alçaram a revolta farroupilha aos céus da estruturação da legitimação institucional de seu governo no Rio Grande do Sul como um de seus elementos simbólicos centrais. Livros foram escritos, festas instituídas e heróis cultuados, ao lado do "patriarca do Rio Grande", o próprio Júlio de Castilhos, após sua morte em 1903. Mesmo na Constituição do Estado do Rio Grande do Sul de 1891, cujo projeto fora elaborado por Castilhos e depois aprovado quase sem mudanças pela Assembleia Constituinte estadual, há dois dispositivos muito significativos a este respeito. Um deles definia que seriam as "insígnias oficiais do Estado as do pavilhão tricolor da malograda República Rio-Grandense" e um outro propunha que "será elevado, em uma das praças públicas do Estado, um monumento à memória de Bento Gonçalves e de seus gloriosos companheiros de cruzada de 1835, logo que os cofres públicos o permitam, se antes a iniciativa particular não houver satisfeito esse patriótico tributo" (Constituição Política do Estado do Rio Grande do Sul, 1981, artigo único do Título VI e artigo oitavo das Disposições Transitórias). Isto mostra a extrema preocupação dos membros do PRR e de seu líder maior em aproximarem o movimento de 1835 à sua "obra" político-institucional.

Um outro aspecto interessante em enfocar a década de 1880 é que isso nos permite perceber que a identificação entre o PRR e o movimento farroupilha deu-se no contexto de uma luta político-partidária na qual se disputava, entre outros e provavelmente mais 
importantes recursos - como o controle sobre os haveres do governo -, a representação legítima do passado e, nesta, a vinculação com os ditos revolucionários farrapos. Por outra, aquilo que os agentes do PRR já estabilizados no governo passaram a considerar oficialmente como "a" versão do movimento - "democrático", "republicano", "de ideias", "antimonárquico", "federativo" - é o resultado de um processo conflituoso que se deu em diversos níveis de ação: o nível propriamente cultural das ideias que estou enfocando, mas também em outros níveis que cito apenas para lembrá-los, pois não está entre meus objetivos tratálos aqui, como o das relações sociais, dos grupos familiares, das redes sociais, dos recursos militares, das relações com o governo central.

Se, como visto, o texto de Castilhos é bastante explícito em seu caráter instrumental na luta políticopartidária, o de Assis Brasil é muito mais sutil. Foi editado dois anos antes que o artigo de Castilhos, que sem dúvida conhecia o texto e que pode mesmo ter nele se baseado para escrever o seu. Assis Brasil, porém, não redigiu um artigo de jornal. História da República Rio-Grandenseé um livro que seu redator refere ser "historiográfico", um ensaio e uma narrativa baseados nas "leis indefectíveis segundo as quais se efetua o movimento histórico" (Assis Brasil, 1882, p. 586). Ele próprio explicita:

O autor desta narrativa não tem o minimo interesse em ocultar a verdade sobre fatos particulares do grande drama que descreve, porque está certo de que qualquer nódoa parcial seria iluminada e desfeita pela harmonia do conjunto, e mesmo porque o descrédito da causa de 1835 não o seria para a causa de hoje. O interesse que há éo de dizer a verdade histórica, bebida de boa fé nas melhores fontes (Assis Brasil, 1882, p. 720).

Assim se posicionando, Assis Brasil busca uma eficácia simbólica para seu texto que extrapola o mundo das opiniões político-partidárias, das então comummente chamadas "doutrinas", pois o situa no campo da "ciência" e da "verdade natural" (Assis Brasil, 1882, p. 581). Com efeito, depois de analisar a "influência do clima, da natureza e aspecto do solo e da sua consequente capacidade produtora, plasticidade da população original, alimentação, indústria, contágio da raça vizinha" - o que nos remete para os textos históricos, sociológicos e antropológicos mais difundidos no meio acadêmico ocidental da época -, o acento militante se coloca na sua interpretação, que sublinha o caráter específico do Rio Grande do Sul, tanto físico como humano, e a organização federativa como "naturais" - para ele trata-se de um "povo" forjado pela história como "independente", "guerreiro", "auto-suficiente", "vigoroso" e "orgulhoso". Ou seja, ao constatar "cientificamente" as "verdades naturais" sobre o povo, clima, atividades, etc. da província, fundamentalmente elaborando uma "essência" ou "natureza" sobre o caráter de seus conterrâneos, finda por emprestar uma legitimidade científica às características que "descobre" e descreve.

Para deixar claro o conteúdo que Assis Brasil atribui ao que nomeia "natureza" do rio-grandense, a passagem abaixo é significativa:

[...] tipo distinto [...], esse tipo vigoroso e sólido que só por si bastava para explicar o estranho impeto da sua revolução. Ajunte-se ainda a tudo isto um sem-número doutras causas secundárias que a ideia destas desperta; considere-se o sentimento ingênito de orgulho e altivez que ao rio-grandense infunde a contemplação das belezas e da superioridade duma terra que ele tanto ama, terra esplende de maravilhas, predisposta para inclinar todos os espiritos a assomos de entusiasmo poético; considere-se o sentimento de independência latente em cada um pelo convencimento em que todos estão de que a provincia, que contém no seu seio com amplíssima superabundância tudo quanto é necessário à vida, não precisa de vínculos de sujeição a elemento estranho para conservar-se e progredir; considerem-se todos esses fatos, todos esses sentimentos atuando constantemente nos homens por mais dum século, revigorando-se pela persistência, transmitindo-se pela hereditariedade de geração a geração, cada vez mais pronunciados, cada vez mais incisivos: e compreender-se-ão sem esforço a natureza e os efeitos dum movimento que partisse do coração desse povo por tal forma preparado por enérgicos precedentes (Assis Brasil, 1882, p. 617-618).

Em outra passagem, ele complementa: "o povo tornou-se essencialmente guerreiro, os hábitos duma contínua agitação militar incutiram-se fortemente na sua natureza, e, ao mesmo tempo, o fato de defender os seus interesses quase sempre com os recursos próprios, mais ainda o acostumou à ideia de independência" (Assis Brasil, 1882, p. 621-622).

O livro de Assis Brasil foi mandado editar em comemoração aos 47 anos da "imortal revolução do Rio Grande do Sul" (Assis Brasil, 1882, p. 579) pelo Clube Vinte de Setembro, organização republicana formada por estudantes rio-grandenses em São Paulo, entre os quais Assis Brasil e Júlio de Castilhos, "onde o estudo da Revolução Farroupilha e da História Rio-Grandense se tornaria um dos objetivos centrais" (Franco, 1988, p. 21). O texto se situa, portanto, associado a um momento de comemoração, reconhecimento e consagração, mas também de "exílio", aquele do afastamento dos estudan- 
tes provinciais de sua terra natal para um período mais ou menos longo de frequência a uma escola superior. Ao mesmo tempo, ao referir que, conforme citado acima, o "descrédito da causa de 1835 não o seria para a causa de hoje”, estabelece uma forma de vincular, mesmo que por negação, ambos os movimentos.

Bourdieu já salientou que a descrição, por mais científica que se queira, contém um forte acento prescritivo, dependendo dos usos que dela se façam (Bourdieu, 1981, p. 69-73). Tentando mostrar que seu trabalho diferia dos "poucos" anteriormente escritos sobre o assunto, que atribuíam aos fatos causas relacionadas à "exclusiva influência dos indivíduos", Assis Brasil refere que divergia "fundamentalmente de método tão cômodo quanto infecundo", pelo que buscava "esboçar, com a filiação histórica da série de sucessos cuja narração me proponho, as causas que me parece explicarem a $[\ldots]$ origem e prolongamento [do movimento farroupilha]" (Assis Brasil, 1882, p. 586). Porém, uma leitura atenta do livro revela que, embora Assis Brasil procure aplicar ao seu trabalho o "método" acima explicitado, que é baseado nos princípios cientificistas correntes em seu tempo, não deixa de enaltecer certos aspectos que convinham à posição que seu grupo assumia frente à conjuntura das disputas político-partidárias no Brasil da década de 1880. O texto não é estritamente uma "propaganda" federalista ou republicana. Pode ser mesmo considerado um livro de história, o que tornava restrita sua circulação e, com isso, a amplitude de seu público potencial. Contudo, poderia contribuir e, ao que parece, contribuiu para formar uma imagem do conflito adequada aos objetivos do grupo do qual seu redator fazia parte e que se destinava a uma restrita elite com uma razoável formação escolar e cultural que poderia adquiri-lo ou consultá-lo.

Cito abaixo uma passagem do texto que, embora um pouco longa, sintetiza as concepções de Assis Brasil sobre o movimento farroupilha e sobre o trabalho que realizou:

O que essa ordem natural de coisas claramente exigia era que as instituições de que a revestissem não fossem antagônicas com a sua indole. Por toda parte um sistema racional de instituições politicas não deve ser mais do que o reflexo, a repercussão, se assim se pode dizer, do sistema de condições sobre as quais se estabelece. Ora, foi justamente isso o que no Brasil se desconheceu e se negou sempre, com especialidade relativamente ao Rio Grande, e muito mais no tempo do império do que no da colônia. Desta provincia tão caracteristicamente original pretenderam os nossos homens fazer pelo simples e ineficaz influxo da legislação uma parte em tudo igual e semelhante ao todo a que ela apenas por vinculos remotos de afinidade se ligava. Como todos os membros do país, ela foi amarrada ao centro pelos funestos laços da unidade mal entendida. A lei teve o intento insensato de nivelar aquilo em que a natureza havia estabelecido uma sábia e harmônica desigualdade. Quando a força legislativa se ajusta com a da natureza, é profícua e salutar, é como a inteligência guiando e aproveitando as aptidóes do corpo; mas, quando entra em concorrência com ela, operando em sentido oposto, a vitória, que há de caber necessariamente à natureza, é tanto mais funesta quanto desajudada do esforço consciente. Os sucessos do Rio Grande foram uma triste comprovação desta verdade. Grande exemplo, cuja lição eloquente parece, entretanto, não ter até hoje servido àqueles a quem se destinava. Uma organização baseada nos elementos naturais, uma organização federativa, para dizer tudo, estabelecida no tempo oportuno, na qual os grandes órgãos deste extraordinário país exercessem livremente as suas funções, cooperando livremente também para a vida do todo - teria aparado os reduplicados golpes que por vezes estiveram a cortar para sempre o fio da integridade nacional. A liberdade é em tudo uma condição de vida e, por conseguinte, de ordem; quiseram substitui-la pela centralização atrofiante; o resultado foi o que se viu: um protesto enérgico da natureza (Assis Brasil, 1882, p. 619621, grifos meus).

Para Assis Brasil, as causas da revolta, pois, estavam assentadas na falta de correspondência entre as "leis centralizadoras”, entre a organização jurídico-estatal, e as leis da história e da natureza do povo que ele próprio identifica como tais. "Nunca foram tão evidentes os males da centralização, isto é, da ausência de liberdade" (Assis Brasil, 1882, p. 629). Ele associa explicitamente federalismo com liberdade, que "quer dizer o poder de viver soberanamente por si naquilo que só a si diz respeito" (Assis Brasil, 1882, p. 631). As culpas e os males, pois, se voltam para o governo brasileiro, excessivamente centralista, eminentemente arrecadador, sem dar quase nada em troca às províncias asfixiadas e delas exigir os maiores sacrifícios, principalmente no caso do Rio Grande do Sul, pois era quem tinha que arcar com o peso das guerras de fronteira. "Estava rasgada a senda da federação. $\mathrm{O}$ povo não tardou em precipitar-se por ela [...]. E este fenômeno foi geral em todo o Brasil" (Assis Brasil, 1882, p. 631).

Note-se que liberdade aqui não corresponde às noções jusnaturalistas da liberdade individual, é encarada como um tipo de relação com o governo central, é federação. E, justamente, $A$ Federação seria o jornal do PRR, fundado dois anos depois da publicação deste livro e, segundo uma versão, teve o nome sugerido pelo próprio Assis Brasil (Beloch e Abreu, 2001, p. 797). 
Um outro ponto fundamental do livro, que pode ser relacionado ao contexto da década de 1880 , é o de como percebeu seu redator a proclamação da República Rio-Grandense. O conflito que eclodira em 20 de setembro de 1835 devido às "causas naturais" expostas logo obteve a unanimidade entre o povo da província, como não poderia deixar de ser, já que de acordo com sua natureza (Assis Brasil, 1882, p. 685, 691, 699). Os seus adversários, os do "partido retrógrado", por sua vez, são mais ou menos explicitamente apontados como elementos estranhos ou estrangeiros, os "gallegos, título que continuou em voga durante toda a revolução e que, como se sabe, designa na linguagem popular os indivíduos de nacionalidade portuguesa". Assis Brasil refere que Antônio Souza Netto, ao proclamar a República em 11 de setembro de 1836, teria declarado que "o fim da revolução era libertá-la duma odiosa facção retrógrada, principalmente composta de indivíduos estranhos" (Assis Brasil, 1882, p. $634,654,746-747)$. No primeiro ano do levante, os farrapos logram expulsar as autoridades indicadas pelo governo central e buscam estabelecer um diálogo com o regente Feijó. À postura deste Assis Brasil atribui a culpa pelo "sangue derramado no Rio Grande do Sul e, o que é ainda mais lamentável do que o sangue, a inutilização das salvadoras ideias que o patriotismo rio-grandense havia de concretizar e plantar no seio da nação brasileira". O governo central se tornara, pois, estrangeiro, não porque os rio-grandenses se quisessem separar do Brasil ou não se sentissem brasileiros, pelo contrário, como a própria citação acima indica, mas porque centralista e governado por alguém com "selvagens instintos de tirania" (Assis Brasil, 1882, p. 702), artificial, portanto.

Neste sentido é característico o caso do paulista Bento Manuel Ribeiro. Oficial de milícias servindo no Rio Grande do Sul, inicialmente auxilia os revoltosos no levante contra o governador da província. Durante o primeiro ano da revolta, porém, após Feijó indicar outro governador para o Rio Grande do Sul com o objetivo de enquadrar os revoltosos, Bento Manuel, que seria "parente"e "amigo" do indicado, finda por passar-se para o lado do governo central. Era "homem sem ideias e sem cultivo de espírito, um guerrilheiro prático e valente, e nada mais", que se engajara na liça por motivos pessoais, por desavenças com o comandante das armas da província (Assis Brasil, 1882, p. 667). Sua "fidelidade [...] fora sempre posta em dúvida pelos que o conheciam de perto. Sabia-se que este coronel tinha sido envolvido nos acontecimentos levado por fatos especiais, por sentimentos de vingança contra Sebastião Barreto", que era o comandante das armas da província derrubado junto com o governador. "Não o prendiam mais o coração nem a inteligência, que por ela nunca se guiou” (Assis Brasil, 1882, p. 706).
Bento Manuel é contrastado fortemente por aquele que é apontado como seu oposto ético e moral: Bento Gonçalves. Assis Brasil ressalta que a sua "energia não sofria contraste; a bondade do seu coração criara-lhe infinitos e dedicados amigos; a honradez do seu caráter cheio de todas as virtudes, a sinceridade com que defendia as opiniões que abraçara assumiam o valor duma garantia. Bento Gonçalves foi o chefe escolhido unanimemente" (Assis Brasil, 1882, p. 670).

A culpa, pois, pela radicalização do movimento, cujos deflagradores "nunca $[\ldots]$ pensaram, antes $[\ldots \mathrm{da}$ revolta], na separação da província; [pois] tratavam sim de restabelecer a federação em todo o país, o que também era ideia comum a todos os brasileiros ilustres daquele tempo" (Assis Brasil, 1882, p. 657), era do governo imperial, que se tornara estrangeiro e contra a natureza por sua tirania e excessiva centralização. A separação da província foi, nesta perspectiva, uma espécie de último recurso de "honra e patriotismo" ao qual tiveram de lançar mão os revoltosos para a "vitória dos princípios, bem que com enormes sacrifícios", segundo teria dito o coronel Antônio Souza Netto ao proclamar a República Rio-Grandense. Ainda segundo o que Assis Brasil aponta como tendo sido a manifestação de Netto: "O Rio Grande, desligando-se do Brasil, formaria um estado livre e independente, sob a forma republicana, mas [...] conservaria o amor antigo aos irmãos brasileiros e aceitaria em qualquer tempo a confederação de todas as províncias que se colocassem na mesma condição política". Para Assis Brasil, "esse pensamento havia já insensivelmente penetrado o partido revolucionário inteiro" (Assis Brasil, 1882, p. 747-748). Ele resume:

Os revolucionários, porém, apenas queriam a autonomia da provincia, sem que fosse roto o princípio da integridade da grande nação; entretanto a incompatibilidade entre o regime dominante e esta grande aspiração evidenciou-se logo. A independência e a democracia vieram fatalmente, como única solução das ideias liberais bem entendidas. Impuseram-se à vontade dos homens. Foi sempre esta a história das revoluçôes liberais: ou sucumbem debaixo de pressão reacionária, ou a lógica as arrasta à democracia legitima. Muitas vezes os próprios homens que as servem não as compreendem, tiram-lhes o caráter social, o caráter amplo, para atribuir-lhes feições egoísticas e acanhadas. Mas os homens são instrumentos das ideias: trabalham por elas sem saber para que trabalham, sem apreender o conjunto dos fatos a que se dirigem; porque as revoluçóes são como as montanhas de que fala o poeta Hugo: só de longe podem ser vistas da base ao pincaro (Assis Brasil, 1882, p. 749-750). 
Resultado: ninguém e nenhuma lei artificial se podem opor às leis da natureza que governam os homens e a história. Os farroupilhas foram empurrados à solução separatista pela natureza das coisas em jogo naquele momento. Os revoltosos que, sob o ponto de vista do governo central, não passavam de rebeldes traidores são assim transformados em uma espécie de, com o perdão do anacronismo, vanguarda patriótica das aspirações e do caráter, da natureza, de seu próprio povo e da parcela "iluminada" do povo brasileiro. Se chegaram ao limite de romperem os laços políticos com o centro foi por culpa deste. O centro se encontrava, pois, em descompasso com a natureza do povo. Assim, "democraticamente" ele se levanta para defender a "liberdade", ou seja, uma maior autonomia frente ao governo central, pois sua natureza reivindicava "federação" e não "centralização".

Cabe ainda salientar que o sentido que Assis Brasil empresta ao termo "democracia", sem que este esteja explícito, seria mais ou menos o de um "pronunciamento do povo de acordo com a natureza", de acordo com sua "índole liberal", ou seja, "autonomista" e "federalista". Não se trata de uma defesa da democracia como forma de governo, embora confusões possam se estabelecer quanto a isto, e ainda mais no caso de Assis Brasil, pois que, como já salientado, teria se convertido ao "liberalismo", depois de 1891, quando, com efeito, passa a defender o regime representativo e a forma de governo democrática. A este respeito vejam-se seus livros posteriores, notadamente a partir do texto que teve sua primeira edição em 1893, Democracia representativa: do voto e do modo de votar (Assis Brasil, 1931).

Interpretar o texto de Assis Brasil como um mero panfleto de propaganda é por certo subestimá1o. Como referido, não tem o mesmo caráter do artigo, este sim "panfletário", de Júlio de Castilhos. Sem entrar no mérito historiográfico da análise e da narrativa histórica que seu redator propõe, trata-se de um trabalho coerente com o cientificismo que grassava entre as elites culturais brasileiras da época e, talvez, seja o primeiro deste tipo que se produziu sobre o conflito iniciado em 1835. Mas também não se pode deixar de notar que o resultado do mesmo se encaixava bastante bem no rol das preocupações e da campanha político-partidária de certos republicanos brasileiros e, depois, do PRR, pelo qual Assis Brasil foi o único e primeiro membro eleito para a Assembleia Legislativa provincial em 1885.

O caráter menos panfletário do texto também se pode notar, comparando-o com o de Castilhos, por ser pouco acentuada a questão "República", ao contrário do que faz este último. Mas permanece que o cerne das preocupações de Assis Brasil é o problema federativo, ou da liberdade, identificados como aspirações naturais do povo, e que foi também uma das bandeiras mais importantes do PRR ao longo da década de 1880. Através da "ciência" e da propaganda, pois, os membros do PRR buscaram se apropriar do passado, trazendo-o para o seu lado, colocando-se como intérpretes legítimos dele, de sua "essência", de sua "verdade".

Daí que "federação", "liberdade" e "República" findam por se tornar eficazes ideias-força na luta políticopartidária da última década do Império (ver Pinto, 1986), respaldadas nas supostas "tradição" e "natureza" do "povo rio-grandense”. E para isto era importante apropriar-se delas buscando impugnar a identificação entre os partidários de Gaspar Martins e o movimento de 1835. Mas é também digno de nota que muito da interpretação que Assis Brasil faz do evento sobreviveria ao período em questão e seria constantemente reativada como um dos elementos centrais da constituição identitária dos rio-grandenses durante o século $\mathrm{XX}$, sendo a sua leitura mais caricatural e institucionalizada elaborada pelos agentes do chamado Movimento Tradicionalista Gaúcho (MTG) e difundida pelos Centros de Tradição Gaúcha (CTGs), principalmente quanto aos aspectos relativos à suposta natureza do, a partir de certo ponto da dinâmica histórica, "gaúcho".

\section{Referências}

ADORNO, S. 1988. Os aprendizes do poder: o bacharelismo liberal na politica brasileira. Rio de Janeiro, Paz e Terra, 266 p.

ASSIS BRASIL, J.F. de. 1931. Democracia representativa: do voto e do modo de votar. In: P. BROSSARD (org.), Ideias politicas de Assis Brasil. Brasília/Rio de Janeiro, Senado Federal/Casa de Rui Barbosa, vol. 2, p. 17-200.

ASSIS BRASIL, J.F. de. 1882. História da República Rio-Grandense. In: Paulo BROSSARD (org.), Ideias politicas de Assis Brasil. Brasília/Rio de Janeiro, Senado Federal/Casa de Rui Barbosa, vol. 3, p. 569-795.

BELOCH, I.; ABREU, A.A. de (coords.). 2001. Dicionário históricobiográfico brasileiro pós-30. Rio de Janeiro, FGV, $6211 \mathrm{p}$.

BOEIRA, N. 1980. O Rio Grande de Augusto Comte. In: J.H. DACANAL; S. GONZAGA (orgs.), RS: Cultura Eं ideologia. Porto Alegre, Mercado Aberto, p. 34-59.

BOURDIEU, P. 1981. Décrire et Prescrire: note sur les conditions de possibilité et les limites de l'eficacité politique. Actes de la recherche en sciences sociales, 38:69-73.

BOURDIEU, P. 1989. O poder simbólico. São Paulo, Difel, 311 p.

CASTILHOS,J.1928 [1884]. Movimento republicano. In: O. ROSA, Júlio de Castilhos. Porto Alegre, Globo, II parte: escritos políticos, p. 3-5.

CONSTITUIÇÃO POLÍTICA DO ESTADO DO RIO GRANDE DO SUL. 1981. In: J.L. OSÓRIO, Constituição política do estado do Rio Grande do Sul: comentário. Brasília, UnB/Câmara dos Deputados, p. 285-302. 
FALCON, F. 1997. História das ideias. In: C.F. CARDOSO; R. VAINFAS, Dominios da história - ensaios de teoria e metodologia. São Paulo, Campus, p. 91-125.

FRANCO, S. da C.1988. Júlio de Castilhos e sua época. Porto Alegre, Ed. da Universidade/UFRGS, $184 \mathrm{p}$.

PICCOLO, H.I.L. 1998. Vida política no século XIX: da descolonização ao movimento republicano. Porto Alegre, Ed. da Universidade/ UFRGS, 78 p.
PINTO, C.R.J. 1986. Positivismo - um projeto político alternativo (RS: 1889-1930). Porto Alegre, L\&PM, 112 p.

RODRÍGUEZ, R.V.1980. Castilhismo: uma filosofia da República. Porto Alegre/Caxias do Sul, EST/UCS, 160 p.

VENÂNCIO FILHO, A. 1982. Das arcadas ao bacharelismo (150 anos de ensino jurídico no Brasil). São Paulo, Perspectiva, 357 p.

Submetido em: 22/12/2009

Aceito em: 22/02/2010

Luiz Alberto Grijó

Universidade Federal do Rio Grande do Sul

IFCH - Depto. de História

Av. Bento Gonçalves, 9500, Prédio 43311, Campus do Vale

Agronomia, 91501-970, Porto Alegre, RS, Brasil 